\title{
放射線の醱酵微生物學的意義（第3 報）
}

Asp: niger Radiumrasse III ○枸棣酸酸酵條件

霜 三雄

（䇺䜌總督府工業研究所）

昭和 15 年 7 月 2 日受理

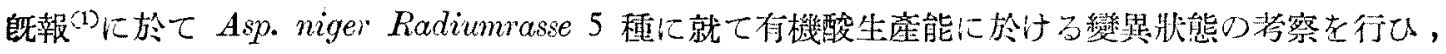

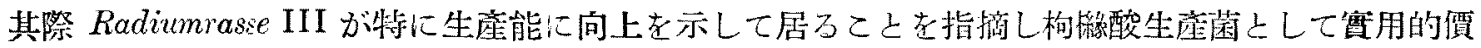

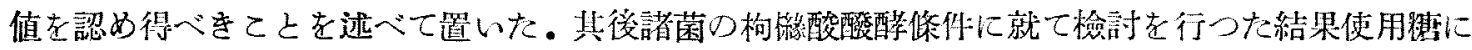

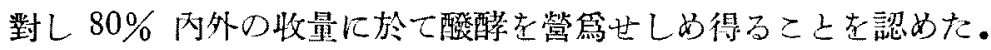

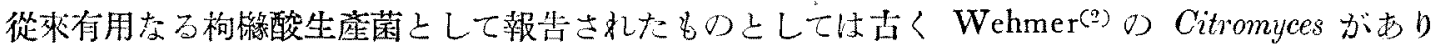

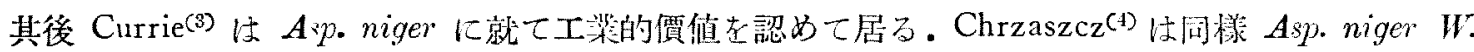

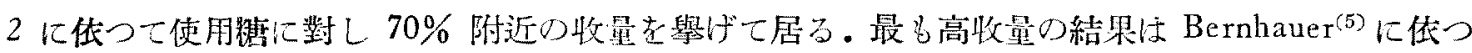
て得ら狆て居り最高生酸率 $80 \%$ 老報じて居る。本邦に於ては坂口博士等のA A . Oryzxe. $K^{(6)}$ 及 び著者等の分離しだ Asp.Awamori var. に依る中澤博士等(7)の硼究があり，最近照讲氏(B)は耐酸

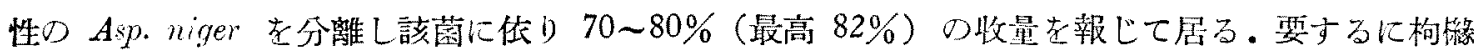

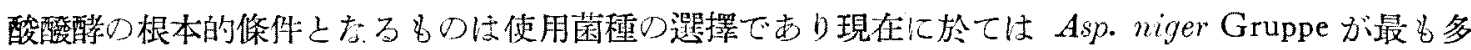

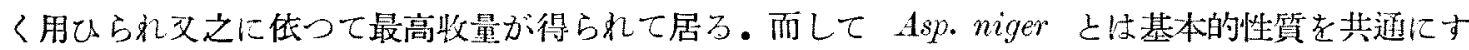
る黑色 Aspergillus の總権であるが故に或一種のAp.niger に就ての研究結果は當然 niger Gruppe

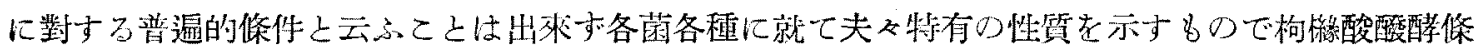

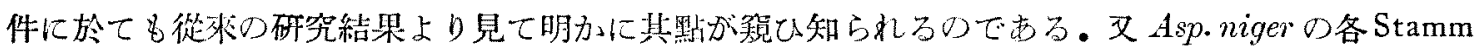
間に形態的特徵上生酸能の並行關係存在の認められないことも落者等の Radiumrasseに於ける形態 と生酸能々の關係に於て知ら扎る所である。即む形態的には一定の方向に變異を生じて居るRadiumrasse 女生酸能等生化學的特性に關しては荃く不規则な猲自な結果考示して居る。Wehmer ${ }^{(9)}$ 及 びIvanov(10) 等は别個のStammの比較に於て前者は閏係無しとし後者は Konidienkopf の形態を生

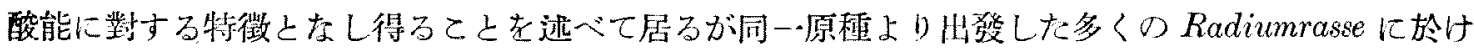
る著者の結果に於ても一定の關係は見出せない. Rhizopus Radiumrasse ${ }^{(1)}$ に就てもこの點に就ては 同栐の結果である。然し乍ら形態的に變異を生ぜる8のは少く々も生酸能又は其他の生化學的特性 に於て多變化を示すことは容易に推惟せらるることでこの默化學的物理的刺㦸に低る所渭 Saltant の研究が實際的興味をも有する所以である.AsF.niger の變異菌箱の酸生成に關しては Kresling(12) の報告が唯一のものであるが—形態のみに關しては古くSchiemann ${ }^{(13)}$ 及び Brenner ${ }^{(14)}$ 等の㸴究 がある一詳細に至らず筫用的價值索有するものは報ぜら炕て居ない。

\section{實 驗 の 部}

\section{1. 寛 驗方 法}

各項に於て时記しない場合に於ては基本組成培養液吉 Fernbach 型 Kolben に $100 \mathrm{cc}$ （液量 cc/ 表面皘 $\overline{\mathrm{cm}}^{2}$ =約 1) 入れたるものに数汁寒天培養の Konidien 考移殖し $30^{\circ}$ に培荃した。酸の定量

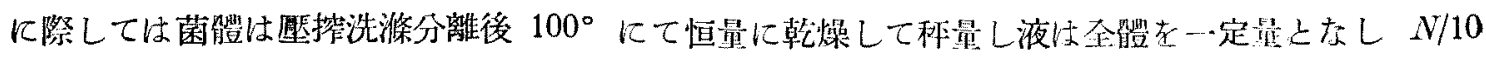




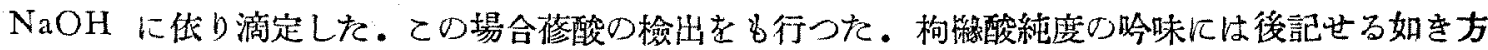

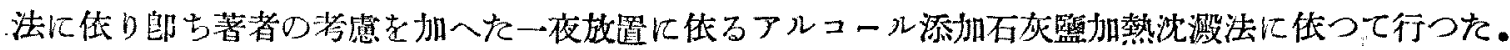

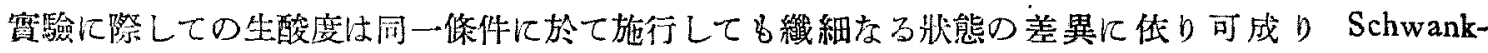

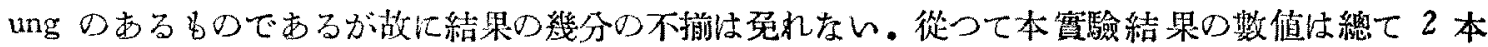
以上の可均值を示したものである。

2. 培羪液の基本組成

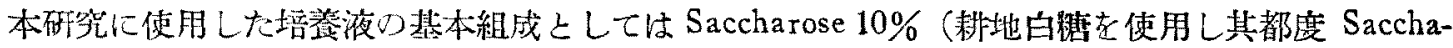
roseの定量老行つた） $\mathrm{NH}_{4} \mathrm{NO}_{3} 0.25 \%, \mathrm{KH}_{2} \mathrm{PO}_{4} 0.1 \%, \mathrm{MgSO}_{4} \cdot 7 \mathrm{H}_{2} \mathrm{O} 0.05 \%, \mathrm{FeCl}_{3} 0.0003 \%$ の 边の左用した。

培養液組成中最も亚要なる役割定有するものは空素源であるが之も研究者に依り使用菌に依つて

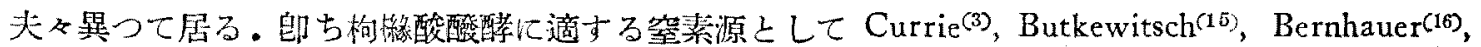
Chrzaszcz(4) 及び Frey(17) 等休 $\mathrm{NH}_{4} \mathrm{NO}_{3}$ 舉げて居り Amelungs(18) は $\left(\mathrm{NH}_{4}\right)_{2} \mathrm{SO}_{4}$ を Kostytschew 及び Tschesnokov ${ }^{(19)}$ は $\mathrm{NH}_{4}$-tartrat t Porges(20) 及中澤博士等(7)は $\mathrm{NaNO}_{3}$ 女 Sotnikov(21) は $\mathrm{Mg}\left(\mathrm{NO}_{3}\right)_{2}$ 蒙舉げて居る。

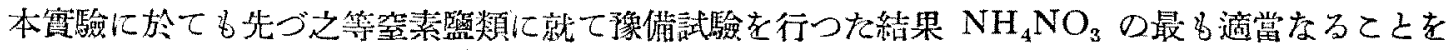
認めたので更にその最岩檤へて惯驗を行つた。

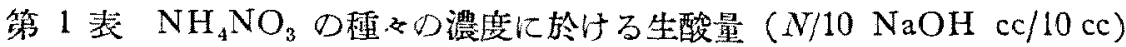

\begin{tabular}{c|c|c|c|c|c|c|c|c}
\hline \multicolumn{2}{c|}{$\mathrm{NH}_{4} \mathrm{NO}_{3} \%$} & 0.05 & 010 & 015 & 0.20 & 0.25 & 0.30 & 0.35 \\
\hline & 4 & 14.8 & 18.4 & 20.3 & 25.4 & 25.0 & 29.4 & 35.6 \\
培 & 6 & 22.4 & 41.4 & 39.5 & 46.8 & 45.3 & 50.3 & 51.0 \\
荃 & 8 & 35.6 & 61.5 & 67.2 & 75.4 & 76.4 & 80.5 & 79.4 \\
日 & 10 & 39.0 & 80.3 & 84.3 & 110.6 & 115.8 & 92.4 & 80.0 \\
數 & 12 & 54.4 & 92.4 & 95.8 & 115.6 & 117.2 & 84.5 & 73.5 \\
& 14 & 60.5 & 97.5 & 105.4 & 106.8 & 110.4 & 72.0 & 54.0 \\
\hline
\end{tabular}

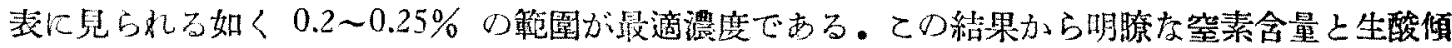

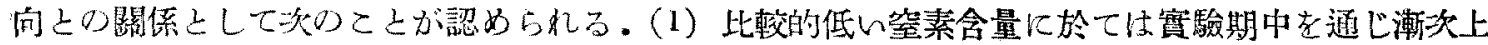

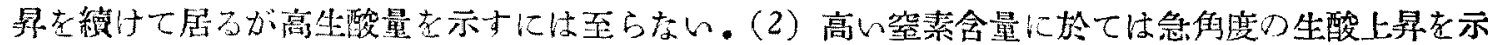

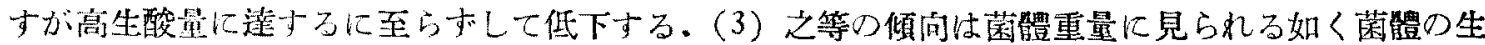

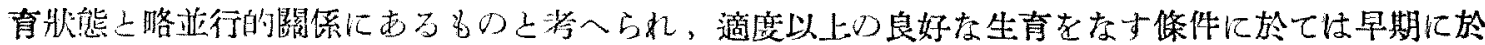

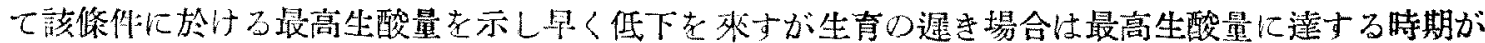

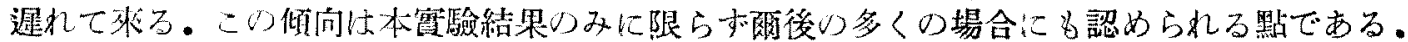

3. 枸移酸定星法心就七

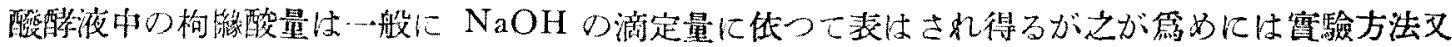

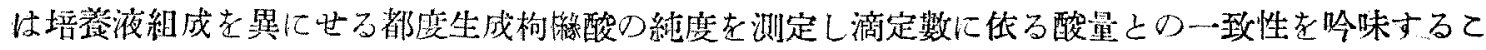

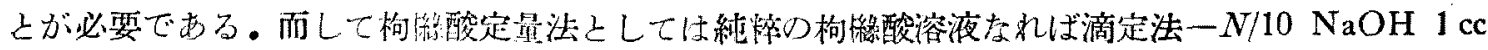

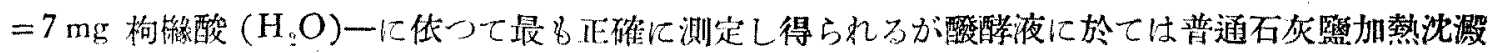




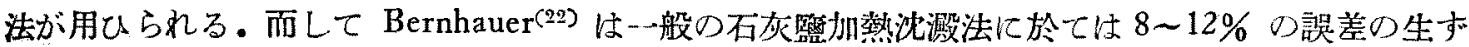
るととを述べ 70〜80\%のアルコール液より沈澱を生ぜしめる時は低溫に於てる加熱處理に於ても

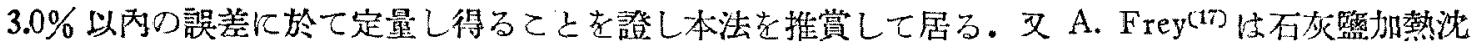
澱法が不正確であるとなし枸䋇酸特有の反應である Pentabromaceton 法を定量に應用し極めて正

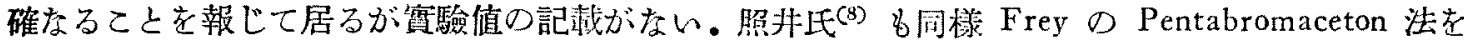

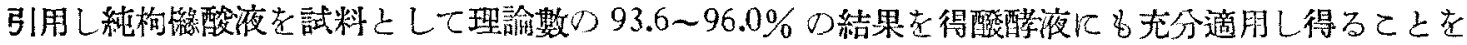

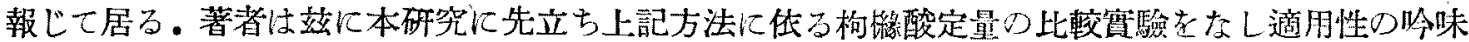
を行つたのである。

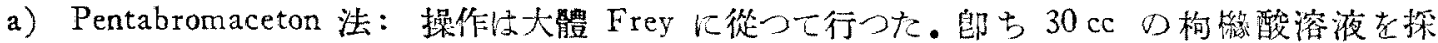
り之に $5 \mathrm{cc}$ の $\mathrm{H}_{2} \mathrm{SO}_{4}(50 \%)$ 及び $3 \mathrm{cc}$ の $\mathrm{KBr}(40 \%)$ t加へて水浴中にて $50^{\circ}$ に溫娠燙しつ

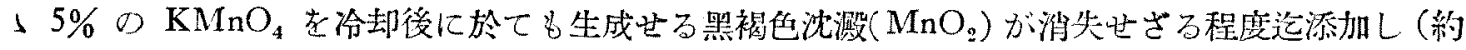

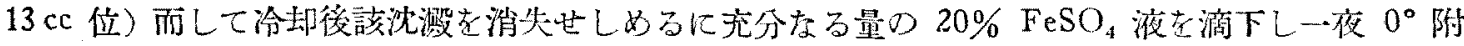

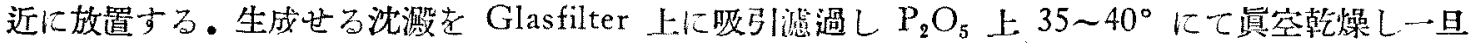
科量後 Pentabromaceton をアルコールにて溶解し去り更にエーテルを䢙じ再び乾燥後科量し前後 の差より試料中の枸緣酸より生成せるPentabromaceton を算出した，Pentabromaceton の理諭的

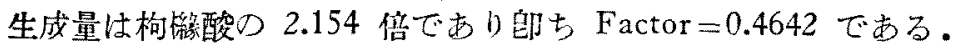

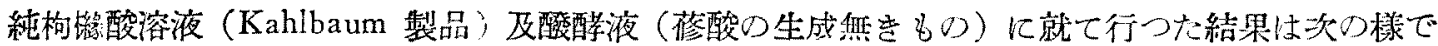
ある・數傎は 3 包口平均值である。

表に見る様に純构橓酸液に於ては試料 中の酸量に從ひ僅かに異るが理諭數に對 し 96〜97\% の正確さが示されて居るが 酸酵液に於ては 93\% 附近であり $7 \%$ 位 の誴差を生ずる。少本結果に於て酸酵液 几於ける實測值つ正確度が純构格酸の場

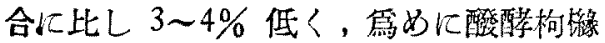
酸の純度が低い是䦓が感ぜられるが後述 の石灰塩法に於て $97.3 \%$ 定し純枸橉

第2表 Pentabromaceton 法に依る 枸檄酸定量結果

\begin{tabular}{|c|c|c|c|}
\hline & \multicolumn{2}{|c|}{ 純圽維酸溶液 } & 醊醭液 \\
\hline 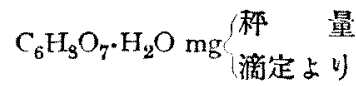 & $\begin{array}{l}135 \\
134.4\end{array}$ & $\begin{array}{l}270 \\
269.5\end{array}$ & 240.1 \\
\hline 洋定數 $\mathrm{N} / 10 \mathrm{NaOH} \mathrm{cc}$ & 19.2 & 38.5 & 31.3 \\
\hline P.B.A. 理論生成量 $\mathrm{mg}$ & 290.8 & 571.6 & 516.9 \\
\hline 定量 P.B.A. 星 & 279.7 & 555.0 & 482.7 \\
\hline 理諭数に對する％ & 96.2 & 97.1 & 93.4 \\
\hline
\end{tabular}

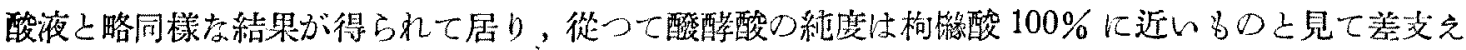
ない。

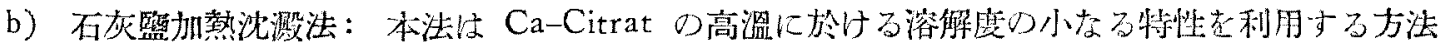
で最も一般的に用ひられてみるものであるが既述の如くBernhauerは加熱のみに依る場合は誤养の

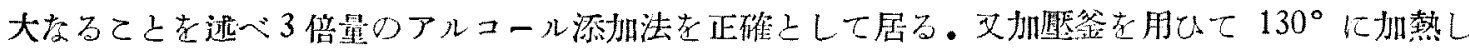

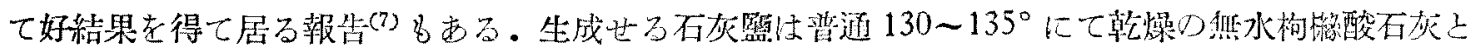
して科量し 0.843 の Factor 支非し $\mathrm{C}_{6} \mathrm{H}_{8} \mathrm{O}_{7} \cdot \mathrm{H}_{2} \mathrm{O}$ 上して算出するのである。

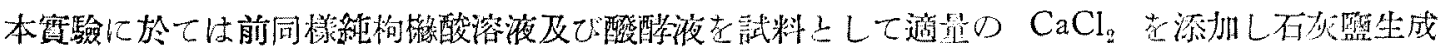

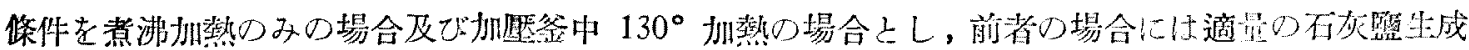

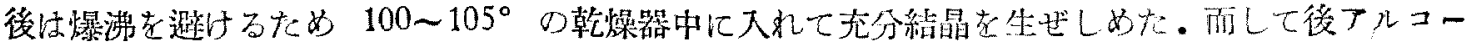


ルを $20 \%$ 添加せる8のと $75 \%$ 几添加せるもの上し，更に後者の場合は，著者の經驗に依り沈溉

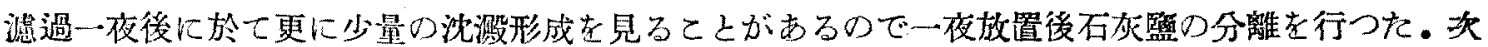

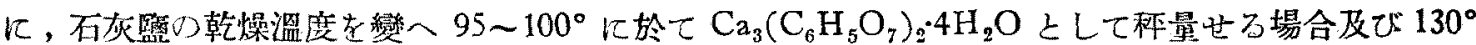

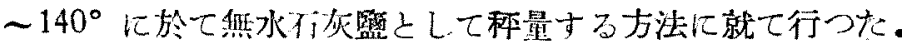

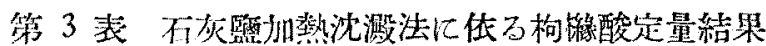

\begin{tabular}{|c|c|c|c|c|c|c|c|c|c|}
\hline 試料 & $\begin{array}{c}\mathrm{C}_{6} \mathrm{H}_{3} \mathrm{O}_{7} \cdot \mathrm{H}_{2} \mathrm{O} \\
\mathrm{mg}\end{array}$ & $\begin{array}{c}\text { 滴定繁 } \\
N / 10 \mathrm{NaOH} c c\end{array}$ & 加熱溫度 & {$\left[\begin{array}{ll}3 & 4 \\
7 & - \\
n & 0\end{array}\right]$} & 濾過染 & 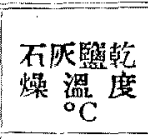 & $\begin{array}{c}\text { 不戻覧量 } \\
\mathrm{mg}\end{array}$ & 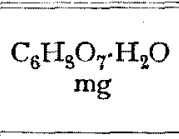 & 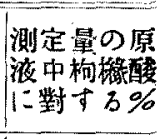 \\
\hline \multirow{6}{*}{$\begin{array}{l}\text { 純 } \\
\text { 构 } \\
\text { 䱚 } \\
\text { 酸 } \\
\text { 溶 } \\
\text { 液 }\end{array}$} & \multirow{6}{*}{270} & \multirow{6}{*}{38.5} & \multirow{2}{*}{100} & \multirow{3}{*}{20} & \multirow{3}{*}{ 直後 } & $95 \sim 100$ & 3261 & 237.7 & 88.0 \\
\hline & & & & & & \multirow{2}{*}{$130 \sim 140$} & 3058 & 2578 & 95.5 \\
\hline & & & 130 & & & & 304.8 & 2570 & 952 \\
\hline & & & & & & $95 \sim 100$ & 339.8 & 2477 & 91.7 \\
\hline & & & 100 & 75 & 一夜後 & & 3155 & 265.9 & 985 \\
\hline & & & 130 & & & & 3158 & 2662 & 986 \\
\hline \multirow{3}{*}{ 眮 } & \multirow{6}{*}{240.1} & \multirow{6}{*}{343} & & \multirow{3}{*}{20} & \multirow{3}{*}{ 直後 } & $95 \sim 100$ & 2878 & 2098 & 87.4 \\
\hline & & & 100 & & & \multirow{2}{*}{$130 \sim 140$} & 270.6 & 228.1 & 950 \\
\hline & & & 130 & & & & 268.9 & 2267 & 944 \\
\hline 䤃 & & & \multirow{2}{*}{100} & \multirow{3}{*}{75} & \multirow{3}{*}{ 一夜後 } & $95-100$ & 301.4 & 219.7 & 915 \\
\hline 液 & & & & & & \multirow{2}{*}{$130 \sim 140$} & 2274 & 2338 & 974 \\
\hline & & & 130 & & & & 2771 & 233.6 & 973 \\
\hline
\end{tabular}

表汇明かな如く 95 100 亿於て乾燥し $\mathrm{Ca}_{3}\left(\mathrm{C}_{6} \mathrm{H}_{5} \mathrm{O}_{6}\right)_{2} \cdot 4 \mathrm{H}_{2} \mathrm{O}$ として科量する時は $10 \%$ 內

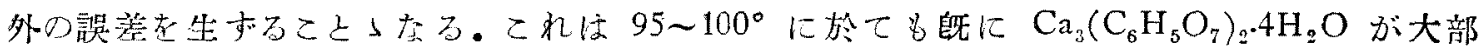
分 $\mathrm{Ca}_{3}\left(\mathrm{C}_{6} \mathrm{H}_{5} \mathrm{O}_{7}\right) \cdot 2 \mathrm{H}_{2} \mathrm{O}$ に移行 ${ }^{(23)}$ することに歸因するもの上䓅人られる・故に一- $2 \mathrm{H}_{2} \mathrm{O}$ として $\mathrm{C}_{6} \mathrm{H}_{8} \mathrm{O}_{7} \cdot \mathrm{H}_{2} \mathrm{O}$ 筑出する時は夫及 $130 \sim 140^{\circ}$ 乾燥の場合の結果之一致するこ之が認められる。文

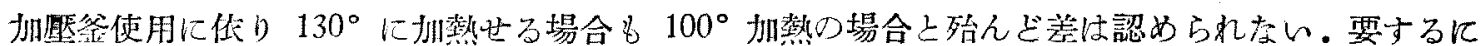

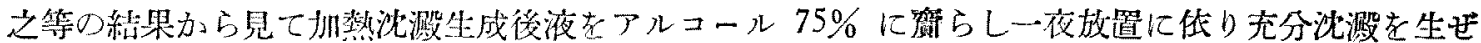

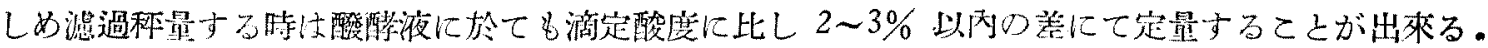

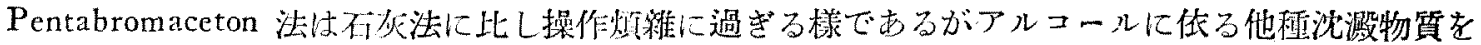
多量に合む試料に於ては同法の適用價值が認的られる。

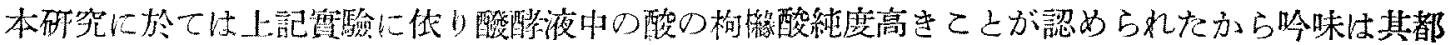
度上記方法に依つて行つたが表中の數值はすべて滴定值より算出せるものである。

\section{4. 水素イオン濃度}

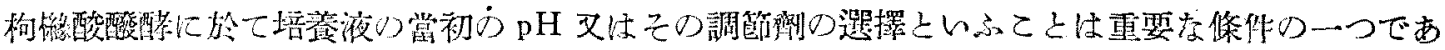

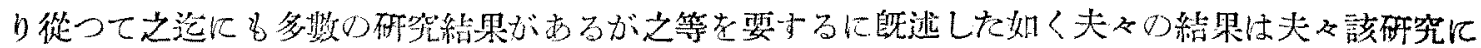

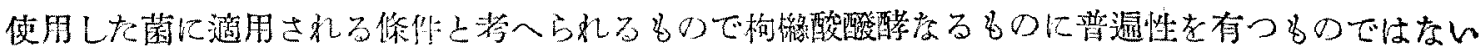

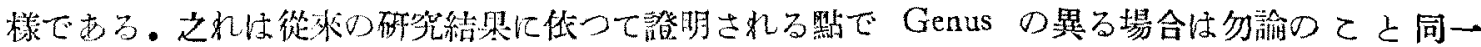


niger Gruppeの\&のに於ても各研究者のStamm に低つて異つた結果が報ぜられて居る。古く构穆 酸生酸菌しして注目された Citromyces に關しては Buchner, Wüstenfeld(4) 等は培琵中 $\mathrm{CaCO}_{3}$ にて中和し中性附近に持ち棑らすここの必要圭述べて居るがFrey(17)は同じくCitromyces glaber に就て $\mathrm{pH}=3 \sim 4$ が最も生酸力大なるこ上考報じて居る.Asp.niger に就ては Butkewitsch(25) は

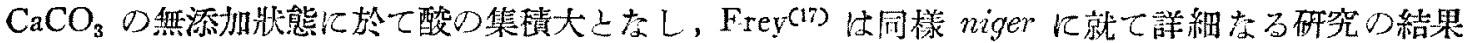
$\mathrm{pH}=2.0$ が最適であるよしてるる. 又 Bernhauer 及び Wulff(96) 並に Fernbach(2) 等は 1.8〜3.0 に $\mathrm{pH}$ 調節すること老推賞して居る.中濢博士等(7) は Asp. Awamori var. fumeusに就て

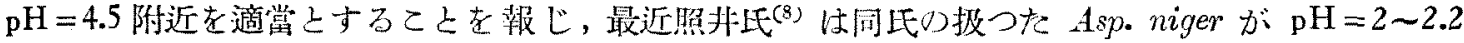
附近及び $\mathrm{pH}=5.2$ 附近の二箇所に最避の現はれること老認め當初 $\mathrm{pH}$ の二元性として報じてるる。 又空素源の種類に低つて最適 $\mathrm{pH}$ の移動するここも述べてるる。斯樣に最適 $\mathrm{pH}$ が酸性側にあるこ 上は共通であるが其の間に於て各菌種に依つて異つて居るものである。

本實驗に於ては $\mathrm{HCl}$ 及び $\mathrm{NaOH}$ にて $\mathrm{pH}=1.44 \sim 6.90$ に調製せる基本組成の液に就て行つた もので絬果は次表の栐である。

第 4 表 $\mathrm{pH}$ と坐酸度 $N / 10 \mathrm{NaOH} \mathrm{cc} / 10 \mathrm{cc}$ (培養液 Saccharose 念量 $9.56 \%$ )

\begin{tabular}{|c|c|c|c|c|c|c|c|}
\hline \multirow{3}{*}{ pli } & \multirow{3}{*}{6 日 } & \multirow{3}{*}{8 日 } & \multirow{3}{*}{10 日 } & \multicolumn{3}{|c|}{12 日 } & \multirow{3}{*}{$\begin{array}{c}\text { 营體重量 } \\
\mathrm{g}\end{array}$} \\
\hline & & & & \multirow{2}{*}{ 澥定敬 } & \multicolumn{2}{|r|}{ 箖酸 } & \\
\hline & & & & & $100 \mathrm{cc}$ 中 $\mathrm{g}$ & 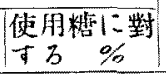 & \\
\hline 1.44 & 45 & 5.0 & 6.0 & 7.9 & 0.553 & 5.78 & 0041 \\
\hline 153 & 4.0 & 5.8 & 8.5 & 12.8 & 0896 & 9.35 & 0102 \\
\hline 1.66 & 11.0 & 17.0 & 24.2 & 30.3 & 2.121 & 22.18 & 0165 \\
\hline 1.80 & 130 & 20.0 & 27.0 & 35.0 & 2450 & 25.63 & 0223 \\
\hline 1.97 & 29.3 & 42.3 & 53.4 & 654 & 4.578 & 47.88 & 0.506 \\
\hline 2.08 & 38.0 & 475 & 600 & 67.4 & 4.718 & 4935 & 0.486 \\
\hline 2.30 & 37.6 & 480 & 537 & 59.8 & 4186 & 4378 & 0.693 \\
\hline 267 & 40.6 & 47.2 & 60.6 & 72.6 & 5.082 & 53.16 & 0.725 \\
\hline 3.04 & 452 & 57.2 & 70.9 & 84.3 & 5901 & 61.72 & 0.834 \\
\hline 3.19 & 52.3 & 70.4 & 970 & 105.7 & 7.399 & 77.39 & 0.822 \\
\hline 3.49 & 45.3 & 67.7 & 83.0 & 98.4 & 6.888 & 7205 & 0.816 \\
\hline 375 & 538 & 723 & 94.8 & 110.2 & 7.714 & 80.69 & 0.924 \\
\hline 403 & 59.5 & 854 & 107.3 & 117.5 & 8225 & 86.03 & 0.845 \\
\hline 4.49 & 60.2 & 72.8 & 98.0 & 111.9 & 7.833 & 81.93 & 0.904 \\
\hline 4.85 & 586 & 71.4 & 838 & 92.1 & 6347 & 66.39 & 0.872 \\
\hline 5.49 & 56.8 & 63.4 & 775 & 86.7 & 6.069 & 63.48 & 0.945 \\
\hline 6.10 & 61.3 & 69.4 & 86.2 & 90.3 & 6.321 & 66.12 & 1.084 \\
\hline 6.52 & 60.4 & 74.8 & 77.7 & 80.5 & 5.635 & 58.94 & 0.937 \\
\hline 6.90 & 62.0 & 75.8 & 785 & 78.0 & 5.460 & 57.11 & 0.954 \\
\hline
\end{tabular}

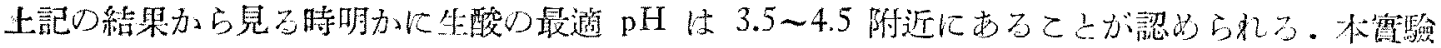

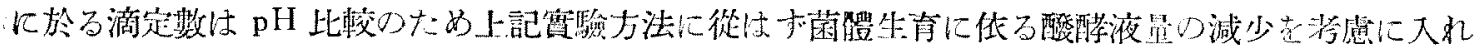

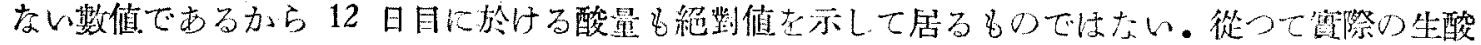

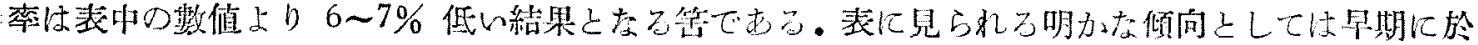


ては一般に生酸量が $\mathrm{pH}$ 高き方向に略直線的に上景してて居ることで，てれが 10 日，12 日に至つ て 3.5〜4.5 の筙園に最適が現はれ，それ以上の $\mathrm{pH}$ てあつては潮次降下を見るに至るのである。

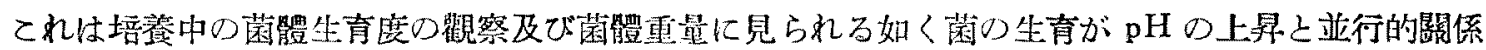
にあるがため生育泉好疗る高 $\mathrm{pH}$ に於てはそれに伴つて酸の生成も早期に於て最高值几達し或程度 の酸の集積绕に於ては生酸作用が抑制せられ低 $\mathrm{pH}$ ○場合上りも早く消損作用が營まれるといふ現

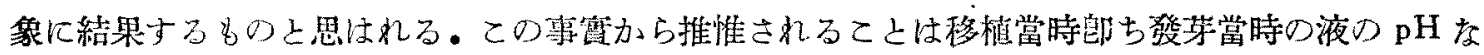
るものは一培埕3日後には總てが 2.0 附近の $\mathrm{pH}$ となる一其後の菌體の生酸能郎ち體內に形成

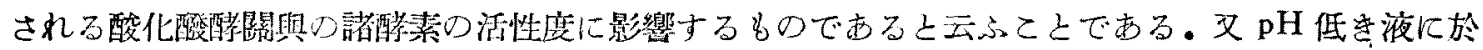

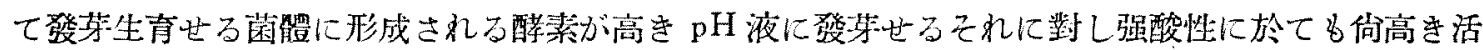
性度在有するものであることが想像される・本菌にあつては最適 $\mathrm{pH} の 二$ 二元性は認められなかつた。

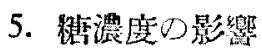

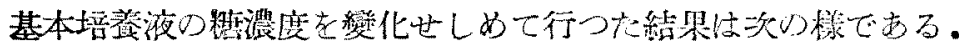

第 5 表 䁌溲度已生酸度

\begin{tabular}{|c|c|c|c|c|c|c|c|c|c|c|c|}
\hline \multirow{2}{*}{ Saccharose $\% / \%$} & \multicolumn{3}{|c|}{$\begin{array}{l}\text { 滴定数 } \mathrm{N} / 10 \mathrm{NaOH} \\
\mathrm{cc} / 10 \mathrm{cc}\end{array}$} & \multicolumn{3}{|c|}{ 枸維酸袁 $100 \mathrm{cc}$ 中 $\mathrm{g}$} & \multicolumn{3}{|c|}{ 生 酸 荤 \% } & \multirow{2}{*}{$\begin{array}{l}\text { 菌體 } \\
\text { 重量 }\end{array}$} & \multirow[b]{2}{*}{ 苳酸 } \\
\hline & 6 & 8 & 10 & 6 & 8 & 10 & 6 & 8 & 10 & & \\
\hline 7.30 & 44.6 & 64.3 & 75.5 & 3.122 & 4.501 & 5.285 & 42.6 & 61.6 & 72.4 & 0.702 & + \\
\hline 10.10 & 47.5 & 86.1 & 109.4 & 3.325 & 6.027 & 7.656 & 32.9 & 59.6 & 75.8 & 0.803 & + \\
\hline 12.16 & 65.8 & 99.8 & 114.3 & 4.606 & 6.986 & 8.001 & 37.9 & 57.4 & 65.8 & 1.077 & + \\
\hline 15.04 & 78.5 & 109.4 & 111.9 & 5.495 & 7.658 & 7.836 & 36.5 & 50.9 & 52.2 & 1.436 & + \\
\hline 19.83 & 56.7 & 78.3 & 92.4 & 3.969 & 5.481 & 6.465 & 20.0 & 27.6 & 32.6 & 1.654 & + \\
\hline
\end{tabular}

菌の生育は或程度踇震度高い程良好であるが酸の生成は之に件はない.10\%附近が生酸率最宫 い。萑酸は何れの場合も少量ではるが生竞される。

6. 培養液量上菌蓋面積の比

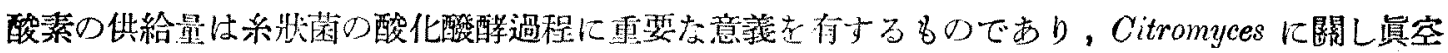

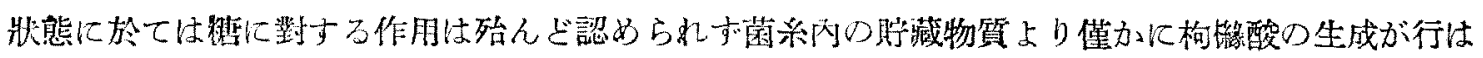
れること，又Avp.niger に閵しては同狀態に於て殆んぼアルコール生成能の示されない事は夫ょ Buchner u. Wüstenfeld(28) 及び Butkewitsch(29)，几依つて述べられて居る所である。而して蜔際的

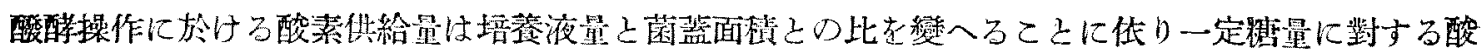

第 6 表 培養液量/菌蓋面程と生酸度 $N / 10 \mathrm{NaOH} \mathrm{cc} / 10 \mathrm{cc}$

\begin{tabular}{|c|c|c|c|c|c|}
\hline \multirow{2}{*}{ 培養日哤 } & \multicolumn{5}{|c|}{ 剒蕉液量 $\mathrm{cc} /$ 莦筑面啧 $\mathrm{cm}^{2}$} \\
\hline & 0.5 & 0.75 & 1.0 & 1.5 & 2.0 \\
\hline 8 & 77.6 & 78.8 & 80.6 & 72.6 & 30.4 \\
\hline 10 & 72.0 & 92.5 & 97.8 & 90.4 & 48.0 \\
\hline 12 & 50.4 & 84.6 & 92.4 & 97.8 & 59.8 \\
\hline
\end{tabular}
素供給比志變化せしめてその最適條件を 求めることが出來る。

第6表江於ける如く液量：面積が大上 なるに從し，臫ち精量に對する酸素供給 量比が小となるにつれ生酸の最高が遲れ る傾向が明かでする。乙の結果江於て良 好なる條件上しては1.0〜1.5附站である ことが考へられる。 
7. 培 食 盕 度

$15,20,25$,及び $30^{\circ}$ に於て行つた。

表に於ける如く早期に於ける菌の 生育 $30^{\circ}$ に於て最最良好なるため酸 の集樍大であるが 10 日後に於ては $25^{\circ}$ に於て最高值が現はれ生酸率 83.7\%に達した. $15^{\circ}$ に於ては繁殖 極めて惡い。又低溫に於ては葆酸の 生成が抑制される傾向が認められ た.

8. 微量要素の影留
第 7 表 培養溫度上生酸度（培養 液 Saccharose $10.06 \%$ )

a) $\mathrm{Fe}$ ：一般に糸狀菌培飬液に於ける $\mathrm{Fe}$ の微量の存在は菌の生青に好絬果在简らすもので枸

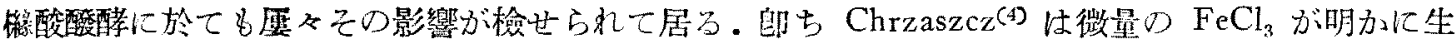

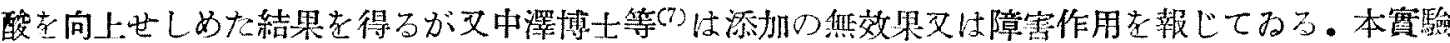
に於ても $\mathrm{FeCl}_{3}$ の形に於て添加した．乙の場合の培養液の基本組成は $\mathrm{FeCl}_{3}$ 除いたものである。

第 8 表 Fe 添加量上生酸度(培差 10 日，培食液の Saccharose 9.93\%)

\begin{tabular}{|c|c|c|c|c|c|c|c|c|}
\hline \multicolumn{3}{|c|}{$\mathrm{Fe}$ 元素量 $100 \mathrm{cc}$ 中 $\gamma$} & 1000 & 500 & 100 & 50 & 10 & 0 \\
\hline 㵜定嘍 & $N / 10$ & $\mathrm{NaOH} \mathrm{cc/10} \mathrm{cc}$ & 31.4 & 67.8 & 109.6 & 106.7 & 105.8 & 88.4 \\
\hline & & $100 \mathrm{cc}$ 中 $\mathrm{g}$ & 2.198 & 4.746 & 7.672 & 7.469 & 7.406 & 6.288 \\
\hline 1007 & ! & 生 酸 & 22.13 & 47.79 & 77.26 & 75.21 & 74.58 & 63.32 \\
\hline 菌 & 體 & 重 & 1.467 & 1.252 & 0.903 & 0.858 & 0.784 & 0.708 \\
\hline
\end{tabular}

$\mathrm{Fe}$ の量 $100 \mathrm{cc}$ 中 $100 \gamma$ 師ち $\mathrm{FeCl}_{3}$ 上して $0.0003 \%$ 迄は生酸の上昇が認められるが $500 \gamma$ 以

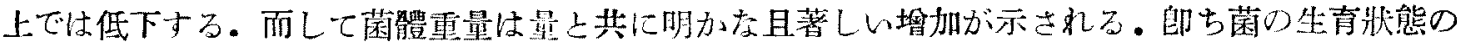
良好に過ざる場合は密乃生酸作用は抑制される。

b) $\mathrm{Zn}: \mathrm{ZnSO}_{4}$ の形に於て使用した。

$\mathrm{Zn}$ 量の埥加に從ひ 第 9 表 $\mathrm{Zn}$ 㬄加量と生酸庋

生酸能の抑制が認めら （培鉒 10 日，培䓹液の Saccharose 9.93\%)

れる. Fe の同時添加 に於ても標準に達しな レ. この場合菌體重量 には萿しい差異は認め られなかつた。

\begin{tabular}{|c|c|c|c|c|c|}
\hline $\mathrm{Zn}$ 元素量 $100 \mathrm{cc}$ 中 $\gamma$ & 1000 & 500 & & $\begin{array}{l}00 \\
+100 \mathrm{Fe}\end{array}$ & 0 \\
\hline 滴定婹 $N / 10 \mathrm{NaOH} \mathrm{cc/10cc}$ & 73.4 & 83.8 & 82.6 & 88.3 & 94.5 \\
\hline 枸 栍 酸 $\left\{\begin{array}{l}100 \mathrm{cc} \text { 中 } \mathrm{g} \\
\text { 生酸率 }\end{array}\right.$ & $\begin{array}{c}5.138 \\
51.74\end{array}$ & $\begin{array}{l}5.866 \\
59.07\end{array}$ & $\begin{array}{c}5.782 \\
58.23\end{array}$ & $\begin{array}{c}6.181 \\
62.24\end{array}$ & $\begin{array}{c}6.615 \\
66.61\end{array}$ \\
\hline
\end{tabular}

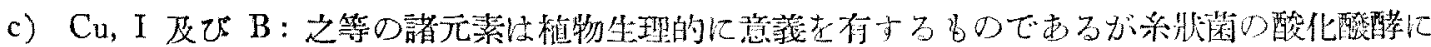

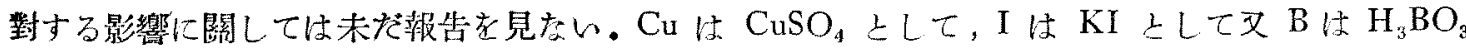
の形に於て添加した。 
第 10 表 $\mathrm{Cu}$ ， I 及び B の生酸に及寸影響（培食液の Saccharose 10.06\%）

\begin{tabular}{|c|c|c|c|c|c|c|c|}
\hline \multirow{2}{*}{ 元素名 } & \multirow{2}{*}{$\begin{array}{c}\overrightarrow{\mathrm{J}} \text { 素量 } \\
100 \mathrm{cc} \text { 中 } \\
\gamma\end{array}$} & \multirow{2}{*}{ 移植前 $\mathrm{pH}$} & \multicolumn{2}{|c|}{ 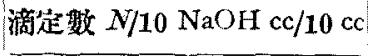 } & \multicolumn{2}{|c|}{ 栋 酸 } & \multirow{2}{*}{$\begin{array}{c}\text { 菌體重量 } \\
\mathrm{g}\end{array}$} \\
\hline & & & 8 日 & 10日 & $100 \mathrm{cc}$ 中 $\mathrm{g}$ & 生醋率\% & \\
\hline \multirow{4}{*}{$\mathrm{Cu}$} & 1000 & 1.25 & 31.0 & 34.4 & 2.408 & 23.94 & 0.404 \\
\hline & 100 & 2.85 & 56.8 & 63.1 & 4.414 & 43.90 & 0.715 \\
\hline & 10 & 3.07 & 70.2 & 76.8 & 5.376 & 53.44 & 0.774 \\
\hline & 1 & 3.13 & 69.6 & 77.2 & 5.404 & 53.71 & 0.785 \\
\hline \multirow{4}{*}{ I } & 1000 & 3.55 & 47.8 & 74.4 & 5.208 & 51.77 & 0.754 \\
\hline & 100 & 3.55 & 58.0 & 80.6 & 5.642 & 56.08 & 0.794 \\
\hline & 10 & 3.51 & 60.3 & 92.3 & 6.461 & 64.22 & 0.772 \\
\hline & 1 & 3.49 & 76.3 & 105.6 & 7.392 & 73.48 & 0.824 \\
\hline \multirow{4}{*}{ B } & 1000 & 3.56 & 56.2 & 80.3 & 5.621 & 55.87 & 0.802 \\
\hline & 100 & 3.72 & 27.8 & 94.8 & 6636 & 65.96 & 0.886 \\
\hline & 10 & 3.76 & 74.4 & 90.5 & 6.335 & 62.97 & 0.915 \\
\hline & 1 & 3.84 & 86.5 & 118.4 & 8.288 & 82.38 & 0.894 \\
\hline Kont & & 3.92 & 78.6 & 99.3 & 6.951 & 69.01 & 0.810 \\
\hline
\end{tabular}

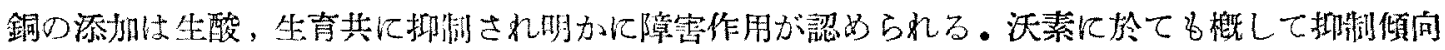

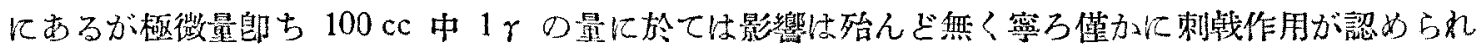

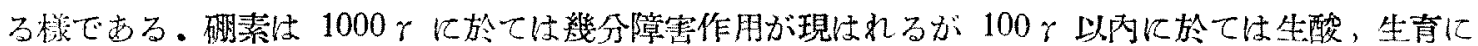
對し共に好影嫏が認められた。

d） U：放射性元素のウラニリム考 $\mathrm{UO}_{2}\left(\mathrm{NO}_{3}\right)_{2}$ の形に於て使用した。

第 11 表 ウラニウムの生酸に及す影響

\begin{tabular}{|c|c|c|c|c|c|}
\hline 元素量 $100 \mathrm{cc}$ 中 $\gamma$ & 1000 & 100 & 10 & 1. & Kont \\
\hline 涺 总 数 & 72.4 & 75.6 & 78.0 & 75.3 & 77.4 \\
\hline$N / 10 \mathrm{NaOH}$ cc/10cc $10 \mathrm{H}$ & 83.4 & 84.6 & 92.2 & 90.4 & 96.7 \\
\hline
\end{tabular}

著しい影響はないが何 れも低下を示して居る。

e) Colchicin : 染色體 倍加竬之して近時植物遺 傳學的方面に使用されつ

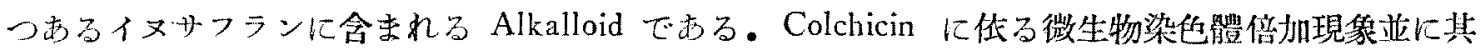
れに件ふ變異種の生成に就ては研究中であり興味ある結果が得られつ」あるが玆には單にこのもの の微量源加几倩る生酸への影響老檢した。

第 12 裴 Colchicin Ф生酸比及寸影響

\begin{tabular}{|c|c|c|c|c|c|}
\hline Colchicin 量 $100 \mathrm{cc}$ 中 $\gamma$ & 1000 & 100 & 10 & 1 & Kont \\
\hline 旗 定 数 & 80.3 & 84.2 & 76.4 & 27.1 & 78.1 \\
\hline N/10 NaOH cc/10ccl10日 & 92.0 & 99.6 & 94.8 & 92.4 & 95.6 \\
\hline 菂 體 重 星 & 0.944 & 0.956 & 0.924 & 0.930 & 0.928 \\
\hline
\end{tabular}

唭萻なる差異は認めら れないが障害作用子現は れて居ない。蜜万適量に 於ては好影響があるもの の㥞である・菌體重量は 僅加貲加の傾向にある

が之を以て染色體倍加體の生成———般に細胞の肥大現侄老呈す一一以確認出來ない。

\section{9. 石灰監の影響}

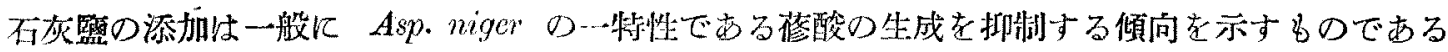


が本實驗に於ても明かに其作用が認められた。然し乍ら多量の添加性酸能を弱め生酸率老低下せ しめる。

第 13 表 $\mathrm{CaCl}_{2}$ の生酸に及寸影響（培養液の Saccharose $9.95 \%$ )

\begin{tabular}{l}
\multicolumn{1}{c}{} \\
\cline { 3 - 8 }
\end{tabular}

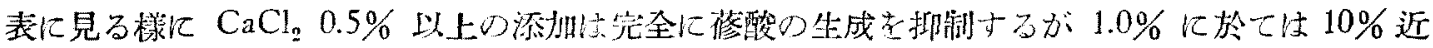
く生酸率低下赤す。

\section{0. 生长素類の影㗽}

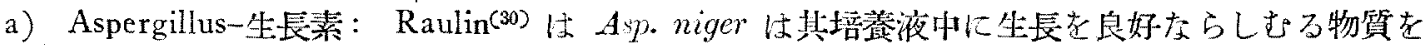

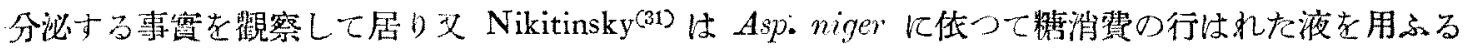
ことに依り菌體重量の增加谱に賄消費の上显老認めてるる。其後 Nielsen一派の研究に依りこの生

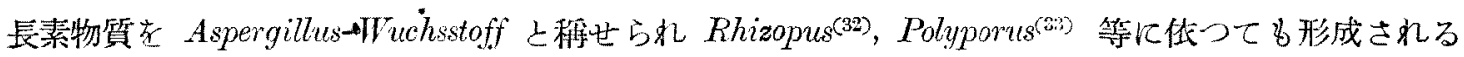
こと老報して居る。弦には本使朋菌を20日間培養せる液を該生長素含有液上して種々の量に添加 し菌體生青並に生酸に及丁影響を檢した。

第 14 表 Aspergillus一坐長素の生酸に及す影鄉

\begin{tabular}{|c|c|c|c|c|c|c|}
\hline \multirow{2}{*}{ 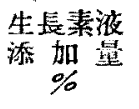 } & \multirow{2}{*}{$\begin{array}{c}\text { 慗植 首1 } \\
\mathrm{pH}\end{array}$} & \multicolumn{4}{|c|}{ 济定酸度 $N / 10 \mathrm{NaOH} \mathrm{cc} / 10 \mathrm{cc}$} & \multirow{2}{*}{$\begin{array}{c}\text { 菌體重量 } \\
\mathrm{g}\end{array}$} \\
\hline & & 移 植 前 & $6 A$ & 8 口 & 10 日 & \\
\hline 0 & 3.88 & 1.0 & 56.0 & 92.3 & 104.2 & 0.826 \\
\hline 0.1 & 3.81 & 1.2 & 50.4 & 85.4 & 100.6 & 0.817 \\
\hline 0.2 & 3.76 & 13 & 60.4 & 86.7 & 105.8 & 0.886 \\
\hline 0.5 & 3.58 & 1.7 & 71.5 & 94.0 & 107.7 & 0.925 \\
\hline 1.0 & 3.30 & 2.2 & 72.3 & 92.5 & 103.9 & 0.847 \\
\hline 2.0 & 2.65 & 36 & 70.7 & 91.6 & 106.0 & 0.914 \\
\hline 5.0 & 2.36 & 6.9 & 74.8 & 102.2 & 120.4 & 0.928 \\
\hline 10.0 & 1.74 & 12.1 & 43.0 & 51.0 & 66.0 & 0.470 \\
\hline
\end{tabular}

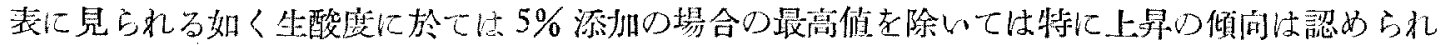

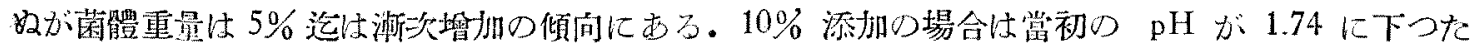

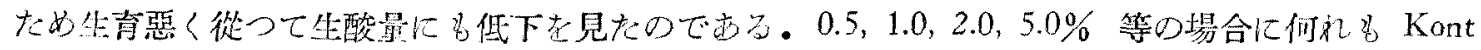

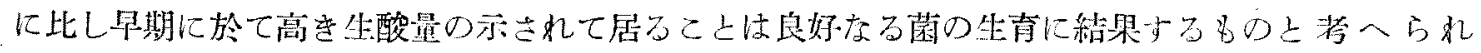

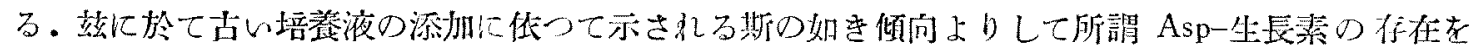

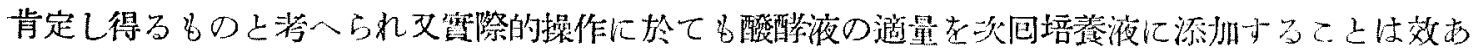
るもの上思溚せられる。 
b) 麥芽汁及び数汁：之等は所謂 Gruppe-B の生長素合有液上見做し得るものて師ち Gruppe $B_{1}$ (Bios-Gruppe) 上 $B_{2}$ (Aspergillus-生長素) 在有するものと考へられる。

第 15 表 麥芽汁及び猌汁の生酸に及す影響

\begin{tabular}{|c|c|c|c|c|c|}
\hline \multirow[t]{2}{*}{$10^{\circ}$} & \multirow{2}{*}{$\begin{array}{l}\text { Bllg 没添加量 } \\
\%\end{array}$} & \multicolumn{3}{|c|}{$\begin{array}{c}\text { 滴 定 酸 度 } \\
N 10 \mathrm{NaOH} \mathrm{cc} / 10 \mathrm{cc}\end{array}$} & \multirow{2}{*}{$\begin{array}{l}\text { 菌體 } \\
\text { 重量 }\end{array}$} \\
\hline & & 6 日 & 8 日 & 10日 & \\
\hline \multirow{2}{*}{ 來 } & E 时 & 50.3 & 80.3 & 104.8 & 0.868 \\
\hline & 1.0 & 57.6 & 86.4 & .94 .5 & 0.954 \\
\hline \multirow{3}{*}{ 楼 } & I 0.1 & 56.6 & 95,2 & 116.5 & 0.903 \\
\hline & RT 1.0 & 64.4 & 92.4 & 102.0 & 0.977 \\
\hline & Kont & 45.5 & 746 & 101.2 & 0.824 \\
\hline
\end{tabular}

上表に見る如く菜芽汁及び猌汗何 れも微量 $(0.1 \%)$ の添加法生酸量の 上昇殊飞早期に於ける生酸の垍大索

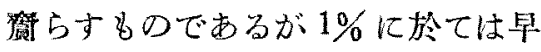
期に於ては最高の生酸量走示すが結 局は Kontrolleの\&のに澾しない。 而して菌體重量は涯加量之共に㝈著 な增加が認为られる・弦に於て既述 の實驗結果に於ても愿及見られた如

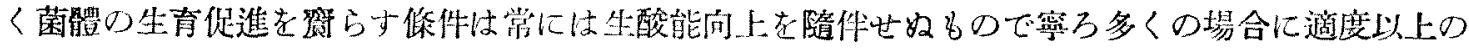
生育促進は生酸に對しては逆效果が示されるのである。郘ち生育著しく良好なる場合は菌體形成に

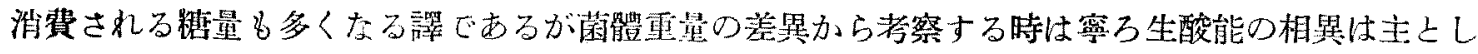

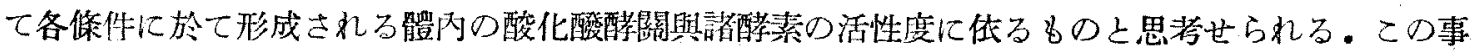

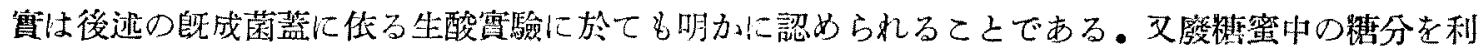
用しての生酸試駿も行つて見たが，その場合の菌體生育は著しく良好であったに反し酸の生成は㱠

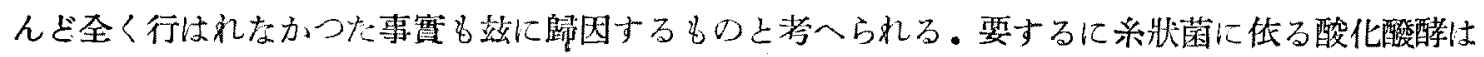
酵母に於けるアルコール酸醉の場合上は異り或程度生育を抑制された條件に於て良好なる生產物收 量を示するのよ云ふこ上が出來る。

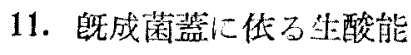

所謂 Bernhauer ${ }^{(22)}$ の “Methode der fertigen Pilzdecken” であり其後 Chrzaszcz: (4) は麥汁及び

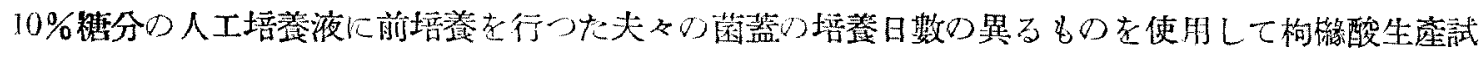
驗老行つて居るが最高生酸率 $41.6 \%$ 孝得たりみで好結果支得て居ない. 本䆓驗に於ては基本組成

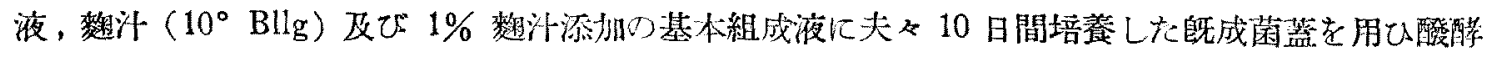

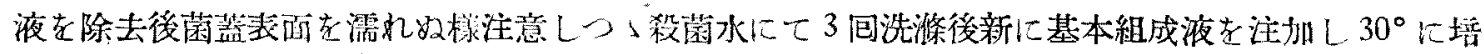
楸した。

第 16 表 既成菌笽に低る生酸能（培養液つSaccharose 9.85\%)

\begin{tabular}{|c|c|c|c|c|c|c|c|c|c|}
\hline \multirow{3}{*}{$\begin{array}{l}\text { 前培意液 } \\
\text { 生酸最 } \\
\text { 培荃日歌 }\end{array}$} & \multirow{2}{*}{\multicolumn{3}{|c|}{$\begin{array}{c}\text { 基 本 組 成 } \\
\mathrm{N} / \mathbf{1} 0 \\
\mathrm{Na}(\mathrm{JH}\end{array}$}} & \multirow{3}{*}{ 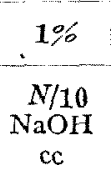 } & \multirow{2}{*}{\multicolumn{2}{|c|}{ 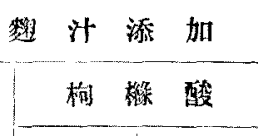 }} & \multicolumn{2}{|l|}{ 䴮 } & \multirow{2}{*}{ 汁 } \\
\hline & & & & & & & \multirow{2}{*}{$\underset{\mathrm{NC}}{\mathrm{N} / 10}$} & 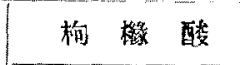 & \\
\hline & & $100 \mathrm{cc}$ 中 $\mathrm{g}$ & 生酸等 & & 100cc中 g & 生酸㛑 & & $100 \mathrm{cc}$ 中 $\mathrm{g}$ & 生酸掌 \\
\hline 4 & 42 & 2.975 & 30.20 & 44.6 & 3.122 & 31.69 & 104 & 0.728 & 7.39 \\
\hline 8 & 56.8 & 3.976 & 4 & 53.0 & 3.710 & 37.66 & 15.7 & 1099 & 11.15 \\
\hline 10 & 64.4 & 4.508 & & 4 & 3.598 & 36 & 6 & 1.232 & 12.51 \\
\hline O & & 091 & & & 0.98 & & & 3.00 & \\
\hline
\end{tabular}

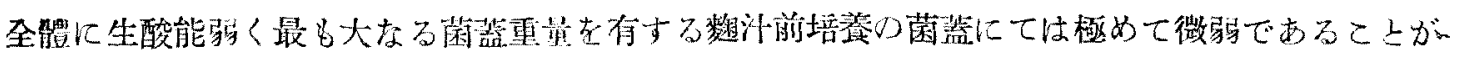




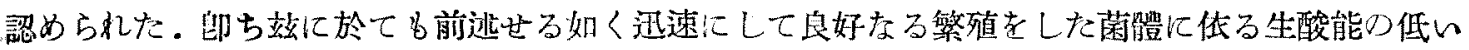
ことが示されて居る。

\section{摘 要}

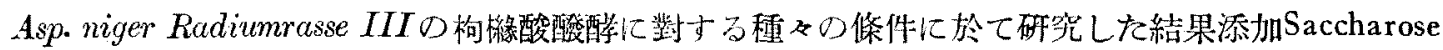

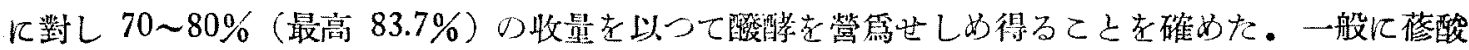

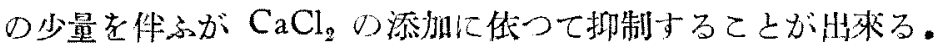

构保酸定量法の比較實驗を行つた絬果Pentabromaceton 法は比較的环確であるが操作煩誰の久點 があり，單なる不灰監加熱沈澱法は誤菱が大をく結局一夜放圆に低るアルコール添加石灰監加熱沈 澱法が最名適用價值大なること認めた。

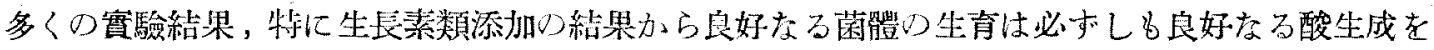

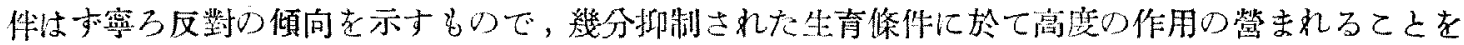
認妨。

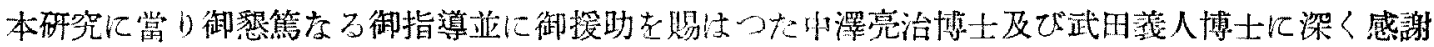
し，終始實驗に御助力されし室友相澤寅男氏に心からの謝意を表士る。

佾本文の要旨は昭和 15 年 4 月 日本焉學會大會に於て䍀演した。

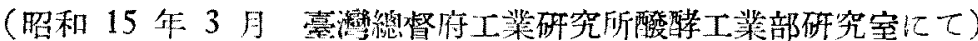

\section{文獻}

（1）中澤，箱：本誌，15，547（1939）

(2) Wehmer, C: Beiträge zur Kenntnis einheimischer Pilze. (1893)

(3) Currie, J. N : Journ. Biol. Chem. 31, 15 (1917)

(4) Chrzaszcz, T. u. Peysos, E: Biochem. Zeits. 280, 325 (1935)

(5) Bernhauer, K. u. Iglaver, A: Biochem. Zeits. 287, 153 (1936)

(6) 坂口，中尾: 釀拹，25，8號，21（1930)

（7）中澤，武田，中野：本誌，13，52（1937）

(8) 照井: 囋學, 17, 839 (1939)

(9) Wehmer, C: Bakt, Zentbl. 49, 145 (1919)

(10) Ivanov, N. N: Chem. Abst. 30, 5256 (1.936)

(11) 籍: 第 4 報未發

(12) Kresling, E. u, Stern, F, Cent. Bakt. II. 95, 327, (1936)

(13) Schiemann: Zeits, f, indukt. Abstam u. Vererbungslehre. 8, 1 (1912)

(14) Brenner: Bakt. Zentbl, 40, 575 (1914)

(15) Butkewitsch: Biochem. Z, 142, 195 (1923)

(16) Bernhauer, Dude u. Siebenäuger: Biochem, Z. 230, 475 (1931)

(17) Frey: Arch. f. Mikrob. 2, 272 (1931)

(18) Amelungs: Z, f. physiol. Chem, 166, 161 (1927)

(19) Kostytschew u. Tschesuokov: Plante 4, 181 (1927)

(20) Porges: Amer. J, of Bot. 19, 7, 559 (1932)

(21) Sotnikov: Compt, rend, de l'Acad. Sci. de l'USSR III, 4, 276, (1934)

(22) Bernhauer: Biochem. Z. 172, 303 (1926)

(23) Beilstein-Prager-Jacobson: Organische Chemie 3, 564

(24) Buchner u. Wüstenfeld: Biochem. Z. 17. 395 (1909)

(25) Butkewitsch: Biochem. Z. 136, 224 (1923)

(26) Bernhauer u. Wulff: Z. f. physiol. Chemie. 177, 270 (1928)

(27) Fernbach: B. P. 266414; 266415, 1927, F. P. 610121; 610122, 1926

(28) Buchner u. Wüstenfeld: Biochem. Z. 17, 395 (1912)

(29) Butkewitsch: Biochem. Z. 154, 177 (1924)

(30) Raulin, J: Ann. des Sci. Nat. Bot. Sèr. V. Vol. 11 (1869)

(31) Nikitinsky, J. H: Jahrb, wiss. Bot. 40, 1 (1904)

(32) Nielsen, N., et Hartelius, V: Compt. Rend. Labor. Carlsb. T. 19. No. 8 (1932)

(33) Nielsen, N: Friesia, I. 5, 290, (1936) 